\title{
Dietary Ca inhibits waterborne Cd uptake in Cd-exposed rainbow trout, Oncorhynchus mykiss
}

\author{
Mohammad Ali Zohouri, Greg G. Pyle ${ }^{1}$, Chris M. Wood* \\ Department of Biology, McMaster University, 1280 Main Street West, Hamilton, ON, L8S 4K1, Canada \\ Received 30 October 2000; received in revised form 7 August 2001; accepted 22 August 2001
}

\begin{abstract}
The effects of chronic exposure to waterborne $\mathrm{Cd}$ and elevated dietary $\mathrm{Ca}$, alone and in combination, were examined in juvenile rainbow trout, Oncorhynchus mykiss. Fish were chronically exposed to 0.05 (control) or $2.56 \mu \mathrm{g} / 1 \mathrm{Cd}$ [as $\left.\mathrm{Cd}\left(\mathrm{NO}_{3}\right)_{2} \cdot 4 \mathrm{H}_{2} \mathrm{O}\right]$ and were fed $2 \%$ body mass / day of control $(29.6 \mathrm{mg} \mathrm{Ca} / \mathrm{g})$ or Ca-supplemented trout food (52.8 mg $\mathrm{Ca} / \mathrm{g}$ as $\mathrm{CaCl}_{2} \cdot 2 \mathrm{H}_{2} \mathrm{O}$ ). Cd accumulated mainly in gill, liver, and kidney. Waterborne Cd inhibited unidirectional $\mathrm{Ca}$ uptake from water into the gill and induced hypocalcemia in the plasma on day 40 . Waterborne Cd also induced an elevated $\mathrm{Ca}$ concentration on day 20 in the gill tissue of trout fed the Ca-supplemented diet and a decreased $\mathrm{Ca}$ concentration on day 35 in the gills of trout fed the control diet. Dietary Ca protected against Cd accumulation in gill, liver, and kidney, but did not protect against the inhibition of $\mathrm{Ca}$ uptake into the gill or plasma hypocalcemia. When fed Ca-supplemented diet and exposed to waterborne $\mathrm{Cd}$, fish showed 35\% mortality, compared to 0-2\% in control fish and in the $\mathrm{Cd}$-exposed fish with normal $\mathrm{Ca}$ in the diet. Growth, on the other hand, was not affected by any treatment. (C) 2001 Elsevier Science Inc. All rights reserved.
\end{abstract}

Keywords: Dietary calcium; Gill; Hypocalcemia; Oncorhynchus mykiss; Rainbow trout; Waterborne cadmium

\section{Introduction}

Cadmium is not an essential element for biological functions in vertebrates. From the water, it is bio-available as a free divalent cation, $\mathrm{Cd}^{2+}$, which is the main agent of toxicity to fish

\footnotetext{
* Corresponding author. Tel.: +1-905-525-9140, ext. 23537; fax: +1-905-522-6066.

E-mail address: woodcm@mcmail.cis.mcmaster.ca (C.M. Wood).

${ }^{1}$ Present address: Department of Biology, Nipissing University, 100 College Dr., North Bay, ON, P1B 8L7, Canada.
}

(Pagenkopf, 1983). Cadmium appears to enter mainly through gill ionocytes ('chloride cells'; Wicklund Glynn et al., 1994) and accumulates mainly in kidney, liver, and gill tissue of fish (Benoit et al., 1976; Roberts et al., 1979). At high waterborne concentrations, cadmium is toxic to fish (Ball, 1967). In addition to causing direct physical damage to gills (Gardner and Yevich, 1970), cadmium disrupts calcium balance leading to acute toxicity (Roch and Maly, 1979; Verbost et al., 1987; Reid and McDonald, 1988). Cadmium irreversibly blocks calcium uptake at the basolateral membrane of gill ionocytes through non- 
competitive inhibition of $\mathrm{Ca}^{2+}$-ATPase (Verbost et al., 1987, 1988, 1989). At the gill surface, cadmium competes with calcium for high-affinity calcium binding sites (Playle et al., 1993a,b; Playle, 1998). The combined action of inhibition of apical calcium uptake and inhibition of $\mathrm{Ca}^{2+}$-ATPase by cadmium leads to acute hypocalcemia (Roch and Maly, 1979; Verbost et al., 1987, 1989).

Water hardness has an ameliorating effect against cadmium uptake and toxicity in rainbow trout (Calamari et al., 1980; Pagenkopf, 1983; Pärt et al., 1985; Pascoe et al., 1986; Hollis et al., 1997, 2000; Richards and Playle, 1999). As water hardness (defined as the sum of calcium and magnesium concentrations, expressed as $\mathrm{CaCO}_{3}$ equivalents; Wetzel, 1983) increases, acute cadmium toxicity decreases (Carrol et al., 1979; Pascoe et al., 1986; Davies et al., 1993). The 96-h $\mathrm{LC}_{50}$ for cadmium is higher in waters having high alkalinity and hardness relative to that in low alkalinity and hardness waters (Calamari et al., 1980). The major hardness cation, calcium, changes gill permeability, competes with cadmium for binding sites on the surface of gills, and reduces toxicity (Calamari et al., 1980; Pagenkopf, 1983; Hunn, 1985; Pärt et al., 1985; Hollis et al., 1997).

Although the ameliorating effects of waterborne calcium on cadmium toxicity in fish are well known, little is known about the possible effects of dietary calcium on waterborne cadmium toxicity. Potentially, a calcium-rich diet may have a similar ameliorating effect as waterborne calcium, in a calcium-deficient environment where fish may be vulnerable towards cadmium toxicity. Areas subjected to acidic precipitation are also often impacted by metal pollution. In such areas, few calcium-rich invertebrate food sources may be available (Mason, 1996). However, if fish were to preferentially exploit the few remaining calcium-rich food sources, they might gain protective benefits. We report here on the interactions between dietary calcium and waterborne cadmium in rainbow trout, Oncorhynchus mykiss. Dietary calcium, supplemented using the inorganic calcium salt calcium chloride $\left(\mathrm{CaCl}_{2}\right)$, protected against the accumulation of cadmium in gill, kidney, and liver of trout. However, dietary calcium did not protect against disturbances in calcium homeostasis caused by waterborne cadmium.

\section{Materials and methods}

\subsection{Experimental animals}

Juvenile rainbow trout weighing $13.5 \pm 0.3 \mathrm{~g}$ $(n=160)$, were obtained from Humber Springs Fish Hatchery (Orangeville, Ontario). Fish were initially held in an aerated 500-1 polyethylene tank that was supplied with $2.0 \mathrm{l} / \mathrm{min}$ hard water (dechlorinated Hamilton tap water), the same water as used in the experimental exposures (composition below). Fish were allowed to acclimate to laboratory conditions for at least 30 days prior to exposure. Fish were fed once per day with commercial trout food (Granulated Hatchery Feed, Corey Feed Mills Ltd, $[\mathrm{Na}]=6 \mathrm{mg} / \mathrm{g}$ of food; $[\mathrm{P}]=11 \mathrm{mg} / \mathrm{g}$ of food; crude protein $=55 \%$; crude fat $=17 \%$; crude fiber $=2 \%$ ) at a rate of $2 \%$ body mass /day. Measured food [Ca] was 29.6 $\pm 1.1 \mathrm{mg} / \mathrm{g}$ of food, $n=14$ and measured food [Cd] was $1.5 \pm 0.1 \mu \mathrm{g} / \mathrm{g}$ of food, $n=10$. Five days prior to the experiment fish were randomly transferred to one of eight identical 200-1 polyethylene tanks where waterborne cadmium and dietary calcium exposures were conducted. Water flow into each tank was maintained at $0.7-0.8 \mathrm{l} / \mathrm{min}$. Organic debris was siphoned daily. Dead fish were removed daily and mortality was recorded.

\subsection{Diet preparation}

Calcium-supplemented diets were prepared by mixing calcium chloride with commercial trout food (Granulated Hatchery Feed, Corey Feed Mills Ltd). Calcium chloride was dissolved in deionized water and mixed with trout food in a pasta maker to give calcium-supplemented food. The paste was air dried for 3 days and analyzed for calcium $([\mathrm{Ca}]=52.8 \pm 5.9 \mathrm{mg} / \mathrm{g}$ of food, $n=$ 8). A control diet (i.e. $[\mathrm{Ca}]=29.6 \pm 1.1 \mathrm{mg} / \mathrm{g}$ of food, $n=14$ ) was prepared using a similar method, but without adding calcium chloride.

\subsection{Experimental design}

The experimental approach consisted of two parts. First, juvenile rainbow trout were exposed to one of four treatments, each replicated in a separate tank for 35 days. Treatments included: (i) sublethal, waterborne cadmium $(2.6 \pm 0.2 \mu \mathrm{g}$ 
Cd/1, $n=32$ ); (ii) Ca-supplemented food (52.8 \pm $5.9 \mathrm{mg} \mathrm{Ca} / \mathrm{g}, n=8$ ); (iii) a combination of (i) and (ii); and (iv) no waterborne cadmium or dietary calcium supplementation (i.e. control). Water chemistry $([\mathrm{Ca}]=1.44 \pm 0.01 \mathrm{mmol} / \mathrm{l}(57.8 \pm 0.5$ $\mathrm{mg} / \mathrm{l}), n=24 ;[\mathrm{Na}]=0.61 \pm 0.01 \mathrm{mmol} / \mathrm{l}, n=8$; $[\mathrm{Cl}]=0.70 \pm 0.01 \mathrm{mmol} / 1, n=14 ; \mathrm{pH}=7.18 \pm$ $0.02, n=32$; temp. $=8.7 \pm 0.1^{\circ} \mathrm{C}, n=32$ ) was monitored every few days with an emphasis on $\mathrm{Cd}$ analyses. Background $\mathrm{Cd}$ concentration was 0.05 $\pm 0.03 \mu \mathrm{g} / \mathrm{l}(n=12)$ and the elevated sublethal Cd concentration of $2.6 \pm 0.2 \mu \mathrm{g} \mathrm{Cd} / 1(n=32)$ was chosen based on $10 \%$ of the hard water $96-\mathrm{h}$ $\mathrm{LC}_{50}$ value in our water, which is approximately $30 \mu \mathrm{g} / \mathrm{l}$ (Hollis et al., 1999). Approximately 80 fish were assigned at random to one of two replicates in each treatment. A main head tank supplied water to four mixing tanks, which in turn supplied two 200-1 polyethylene tanks each with a flow of $0.7-0.8 \mathrm{l} / \mathrm{min}$. Two mixing tanks, chosen at random, received waterborne cadmium delivered via Marriott bottles [added as $\mathrm{Cd}\left(\mathrm{NO}_{3}\right)_{2}$. $4 \mathrm{H}_{2} \mathrm{O}$, diluted in de-ionized water: $18 \mathrm{mg} \Omega$, Nanopure II]. Fish were sampled for tissue cadmium concentrations at 10,20 , and 35 days during the exposure. Some mortality occurred in one of the treatment groups after day 20 (see Section 3); obviously sick fish were not sampled. After day 35, waterborne exposure was continued but feeding of the diets was suspended for a 5-day period before physiological tests were performed. The goal here was to ensure that mortality had largely ceased (see Section 3) and to avoid any immediate effect of feeding on physiology. On day 40 , surviving fish were either blood sampled for plasma calcium concentration or were subjected to a 4-h gill Ca-uptake assay, using ${ }^{45} \mathrm{Ca}$.

\subsection{Sampling and metal analysis}

On days $0,10,20$ and 35 of chronic waterborne cadmium exposure, rainbow trout (day $0: n=16$, 2 from each tank as all treatments were identical on day 0 ; subsequent days: $n=12$ per treatment, 6 from each tank) were removed from each tank and quickly sacrificed with a blow to the head. Weight and length of each fish was measured. Routine dissections included removal of whole gills, liver, kidneys, and carcasses. Tissue samples were refrigerated at $4^{\circ} \mathrm{C}$ prior to subsequent calcium and cadmium analysis. On day 40, blood samples were taken via caudal puncture into hep- arinized 1-ml syringes. Whole blood samples were centrifuged at $10000 \times g$ for $5 \mathrm{~min}$ to separate plasma. Plasma samples were analyzed for calcium concentration. Day 10 liver and carcass samples were lost due to a procedural error.

Gills, kidneys, livers, and carcasses were digested in 3-5 volumes of $1 \mathrm{~N} \mathrm{HNO}_{3}$ for $24 \mathrm{~h}$ at $60-80^{\circ} \mathrm{C}$. Water samples $(5 \mathrm{ml})$ were acidified using $50 \mu \mathrm{l}$ of $1 \mathrm{~N} \mathrm{HNO}_{3}$. Tissue and water samples were analyzed for cadmium and calcium using graphite furnace (GFAAS) and flame (AAS) atomic absorption spectrophotometry, respectively (Varian AA-1275 fitted with a GTA-95 Graphite Tube Atomizer, Mississauga, Ontario).

Whole body metal concentrations (WB) were determined using the following formula:

$$
\begin{aligned}
\mathrm{WB}= & \left(\left(G^{*} m_{\mathrm{G}}\right)+\left(K^{*} m_{\mathrm{K}}\right)+\left(L^{*} m_{\mathrm{L}}\right)\right. \\
& \left.+\left(C^{*} m_{\mathrm{C}}\right)\right) /\left(m_{\mathrm{WB}}\right)
\end{aligned}
$$

where $G$ is the gill metal concentration, $K$ is the kidney metal concentration, $L$ is the liver metal concentration, $C$ is the carcass metal concentration, $m_{\mathrm{WB}}$ is the mass of whole body tissue, $m_{\mathrm{G}}$ is the mass of gill tissue, $m_{\mathrm{K}}$ is the mass of kidney tissue, $m_{\mathrm{L}}$ is the mass of liver tissue, and $m_{\mathrm{C}}$ is the mass of carcass tissue. WB was calculated for each individual fish, and tests demonstrated that cadmium losses during dissection were less than $5 \%$ of the total WB value.

\subsection{Calcium uptake kinetics}

On day 40, unidirectional $\mathrm{Ca}^{2+}$ uptake from the water into the gills was determined by exposing fish for $4 \mathrm{~h}$ to radioactive ${ }^{45} \mathrm{Ca}$ (Hogstrand et al., 1994) in the appropriate exposure water. Exposure waters were taken directly from the tanks that housed the fish for 40 days and thus either contained elevated waterborne cadmium or not, as appropriate. Twelve fish from each treatment (6 per replicate) were placed into 5-1 clear plastic bags which were provided with aeration, and housed in a water bath to maintain temperature $\left(8^{\circ} \mathrm{C}\right)$. Five minutes before fish were added to the bags, $2 \mu \mathrm{Ci} / 1{ }^{45} \mathrm{Ca}$ was added as ${ }^{45} \mathrm{CaCl}_{2}$ (specific activity $=10 \mathrm{mCi} / \mathrm{mM}$; New England Nuclear, Boston, MA). Duplicate water samples of $5 \mathrm{ml}$ were taken at 0 and $4 \mathrm{~h}$. After the 4-h exposure, fish were removed and quickly sacrificed with a blow to the head. Gills were excised and rinsed 
for $10 \mathrm{~s}$ in $5 \mathrm{ml}$ de-ionized water to displace loosely bound ${ }^{45} \mathrm{Ca}$. Gill tissue and water samples were frozen for future analysis. Gill tissues alone were analyzed, because our goal was to look at branchial effects only, and not whole body $\mathrm{Ca}^{2+}$ uptake which may be complicated by a substantial uptake component across the skin (e.g. Perry and Wood, 1985). A distilled water rinse, rather than a cold calcium displacement or EDTA rinse, was employed as we did not wish to displace ${ }^{45} \mathrm{Ca}$ from specific high affinity surface sites which are likely part of the $\mathrm{Ca}^{2+}$ uptake process into gills (Playle et al., 1993a,b).

Following the procedure of Hogstrand et al. (1994), frozen fish gills were transferred to liquid nitrogen and ground to a fine powder with mortar and pestle. Powdered gill samples $(0.5 \mathrm{~g})$ were placed in glass scintillation vials. Samples were digested in a $2.0-\mathrm{ml}$ liquid tissue solubilizer (NCS, Amersham) for $48 \mathrm{~h}$ at $45^{\circ} \mathrm{C}$. Samples were then neutralized with $20 \mu \mathrm{l}$ of glacial acetic acid, diluted in $10 \mathrm{ml}$ of scintillation fluor (OCS, Amersham) and counted for ${ }^{45} \mathrm{Ca}$. In addition, one of each water sample duplicate $(5 \mathrm{ml})$ was diluted in $10 \mathrm{ml}$ of scintillation fluor (ACS, Amersham) and counted for ${ }^{45} \mathrm{Ca}$. Counting efficiencies were determined by internal standardization, i.e. by addition/recovery tests of known amounts of ${ }^{45} \mathrm{Ca}$. The remaining water samples were analyzed for cadmium and calcium using GFAAS and AAS, respectively.

Tissue and water ${ }^{45} \mathrm{Ca}$ was counted on a liquid scintillation counter (LKB Wallac 1217 Rackbeta, Pharmacia-LKB AB, Helsinki), after gills were digested. The inward flux $\left(J_{\text {in }}\right)$ for $\mathrm{Ca}^{2+}$ (in $\mu \mathrm{M} / \mathrm{kg} / \mathrm{h}$ ) into the gills was calculated according to the formula from Hogstrand et al. (1994):

$J_{\text {in }}=\mathrm{ACT} /(\mathrm{SA} * \mathrm{CE} * t)$

where 'ACT' is the average counts in gill samples (cpm/ $\mathrm{kg}$ gill tissue), 'SA' is the measured mean specific activity of ${ }^{45} \mathrm{Ca}$ in the water $(\mathrm{cpm} / \mu \mathrm{mol})$, ' $\mathrm{CE}$ ' is the relative counting efficiency of the 'tissue-solubilizer-fluor system', compared to the 'water-fluor system', and ' $t$ ' is time (h).

\subsection{Statistical analysis}

All data have been expressed as mean \pm 1 S.E. $(n)$. Mean values were analyzed for statistical significance between treatments by using a oneway ANOVA followed by a 'post hoc' Tukey's $b$ test to compare treatment means to one another. The level of significance was $P<0.05$.

\section{Results}

\subsection{Fish mortality}

Mortality of juvenile rainbow trout (corrected for sampling) exposed to the combination of dietary calcium and waterborne cadmium was significantly higher $(35 \pm 4 \%$ at day $35, n=2$ tanks of approx. 80 fish each) than mortality of fish in the other three treatments (dietary calcium only treatment: $1 \pm 0 \%, n=2$; waterborne cadmium only treatment: $2 \pm 2 \%, n=2$; control: $0 \pm 0 \%$, $n=2$ ). (Fig. 1). Elevated mortality in this treatment group started after day 20, was first significant $(P<0.05)$ relative to the control group at day 25 , was at its greatest from days 30 to 35 , and had slowed considerably by day 40 (Fig. 1). Fish growth was not affected by any treatment and averaged $0.12 \pm 0.02 \mathrm{~g} /$ fish/day $(n=48)$. Over the 35 days, weight increased by $37 \pm 5 \%(n=48)$ and total length increased by $6 \pm 1 \% \quad(n=48)$. Furthermore, there were no differences in water chemistry of the eight tanks.

\subsection{Cadmium accumulation}

Waterborne cadmium exposure caused significant cadmium accumulation $(P<0.05)$ in gill, liver, and kidney tissues as well as the whole body of rainbow trout (Figs. 2 and 3). Accumulation of cadmium in gill and kidney (Fig. 2) differed from accumulation in liver and whole body (Fig. 3). By day 35 , in trout which had been exposed only to waterborne cadmium, cadmium accumulated to levels which were 20.4-fold higher in gills (Fig. 2a), 18.0-fold higher in kidney (Fig. 2b), 2.7-fold higher in liver (Fig. 3a), and 1.3-fold higher in whole body (Fig. 3b), relative to those in the control group. In waterborne cadmium exposed fish, simultaneous elevation of calcium in the diet significantly decreased $(P<0.05$, relative to waterborne $\mathrm{Cd}$ exposure alone) cadmium accumulation in these tissues and in the whole body (on day 35: $75 \%$ drop in gill cadmium, $72 \%$ drop in kidney cadmium, $62 \%$ drop in liver cadmium, and 


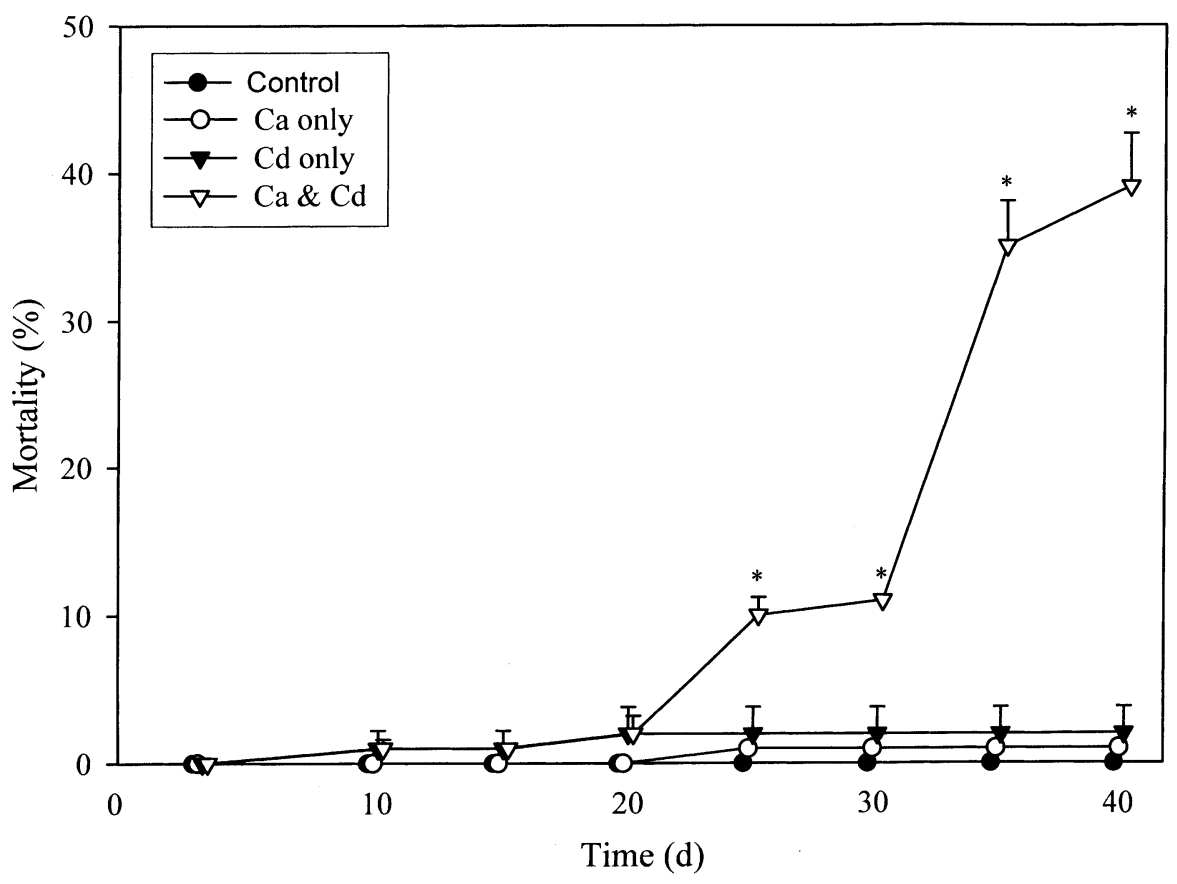

Fig. 1. Percent mortality of juvenile rainbow trout during 40 days. Values are the averages between two replicate tanks $(n=80$ fish per tank at day 0) for each treatment: 'control' (no supplemented Ca diet or waterborne $\mathrm{Cd}$ ), 'Ca only' (supplemented Ca diet and no waterborne $\mathrm{Cd}$ ), ' $\mathrm{Cd}$ only' (waterborne $\mathrm{Cd}$ and no supplemented $\mathrm{Ca}$ diet), and ' $\mathrm{Ca}$ and $\mathrm{Cd}$ ' (both supplemented $\mathrm{Ca}$ diet and waterborne Cd). Statistical comparisons were made against the control treatment $(*) ; P<0.05$.

$24 \%$ drop in whole body cadmium; Figs. 2 and 3). Most of these differences were already apparent by days $10-20$. In fish which were fed Ca-supplemented diet and kept in control water, there was a significant decrease $(40 \%$ drop in gill cadmium on day $35 ; P<0.05)$ of baseline cadmium concentration in gill tissue relative to controls (Fig. 2a). However, no other changes in cadmium concentration were observed in other compartments, except for a slight decrease $(P<0.05)$ in whole body cadmium on day 20 relative to controls (Fig. $3 b)$.

\subsection{Calcium metabolism}

Short-term (4-h) unidirectional calcium uptake into the gills from the water was inhibited by waterborne cadmium relative to controls $(26 \%$ drop in unidirectional calcium influx on day 40 ; Fig. 4a). In addition, cadmium exposure induced significant hypocalcemia $(P<0.05)$ in the blood plasma relative to controls $(6 \%$ drop in plasma calcium on day 40; Fig. 4b). Calcium supplemen- tation through the diet neither protected against inhibition of calcium uptake into gill nor prevented hypocalcemia in plasma (Fig. 4).

After 20 days of exposure to the combination of waterborne cadmium and dietary calcium, calcium concentration in gill tissue significantly increased relative to controls $(17 \%$ increase in gill calcium concentration on day 20; Fig. 5a). However, a reduction of calcium concentration was induced in gills of trout exposed to waterborne $\mathrm{Cd}$ without Ca-supplementation of the diet, an effect which was significant $(P<0.05)$ on day 35 relative to controls $(11 \%$ drop in gill calcium concentration on day 35; Fig. 5a). Reduced calcium levels were also observed in liver tissues of trout that were exposed to waterborne cadmium alone or in combination with dietary calcium $(26 \%$ drop in liver calcium for both treatments on day 20 relative to controls; Fig. 5b). Neither waterborne cadmium nor dietary calcium significantly altered $(P<0.05)$ calcium concentration in kidney or whole body tissues (Fig. 5). However, there were significant decreases $(P<0.05)$ in calcium concentrations, relative to day 0 values, in the kidney, liver, and whole body during the 35-day 


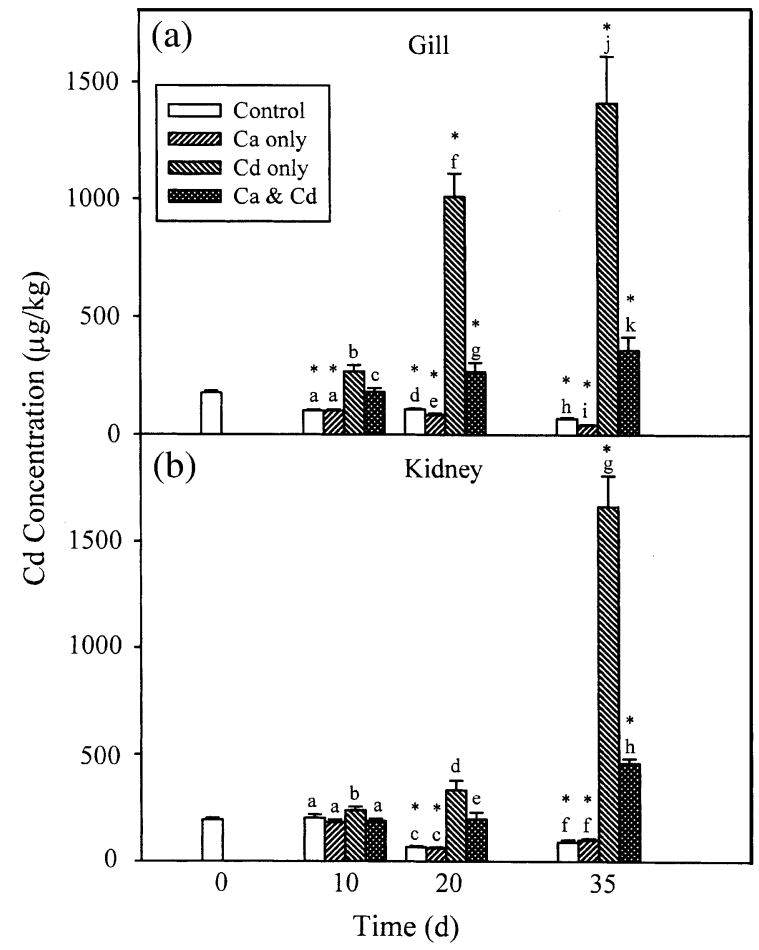

Fig. 2. Accumulation of $\mathrm{Cd}$ in gills (a) and kidney (b) of juvenile rainbow trout during 35 days. Fish ( 0 days: $n=16$; 10 , 20, and 30 days: $n=12$ ) were sampled from each treatment (two replicates): 'control' (no supplemented Ca diet or waterborne $\mathrm{Cd}$ ), 'Ca only' (supplemented $\mathrm{Ca}$ diet and no waterborne $\mathrm{Cd}$ ), 'Cd only' (waterborne $\mathrm{Cd}$ and no supplemented $\mathrm{Ca}$ diet), and ' $\mathrm{Ca}$ and $\mathrm{Cd}$ ' (both supplemented $\mathrm{Ca}$ diet and waterborne $\mathrm{Cd}$ ). Statistical comparisons were made among treatments at each sampling day (letter) and temporally against the initial control $(*)$. Within the same sampling day, treatments sharing the same letter are not significantly different; $P<0.05$.

exposure, likely allometric effects of rapid growth in these small fish (Fig. 5).

\section{Discussion}

The current study has revealed interesting interactions between dietary calcium supplementation and the responses to waterborne cadmium. Based on the observations made throughout the 35-day exposure and subsequent experiments on day 40 , the interaction between calcium and cadmium were manifest through two separate mechanisms. First, in the presence of cadmium, dietary calcium inhibited waterborne cadmium accumulation in gill, liver, kidney, and whole body of rainbow trout (Figs. 2 and 3), and caused an elevation of calcium levels (on day 20) in gill tissue (Fig. 5a). Second, waterborne cadmium blocked unidirectional calcium influx from the water into the gills (Fig. 4a) and caused hypocalcemia (Fig. 4b) regardless of the dietary history, and also induced a lowering of calcium levels in the gill tissue (on day 35) of trout fed a normal diet (Fig. 5a). Doubled dietary calcium when coupled with waterborne cadmium exposure caused $35 \%$ mortality, whereas fish exposed to either cadmium alone or additional dietary calcium alone exhibited negligible mortality (Fig. 1). However, it is important to note that the key trends in cadmium accumulation, and most importantly its reduction by dietary calcium, had already started by day 20 (Figs. 2 and 3), before the start of significant mortality. The protective effects of dietary calcium against cadmium accumulation were even more pronounced by day 35 after significant mortality had occurred in the calcium supplemented treatment. Thus the results were not biased by the 'survivor effect'.

Cadmium accumulation, mainly in gill, liver, and kidney of rainbow trout, has been previously

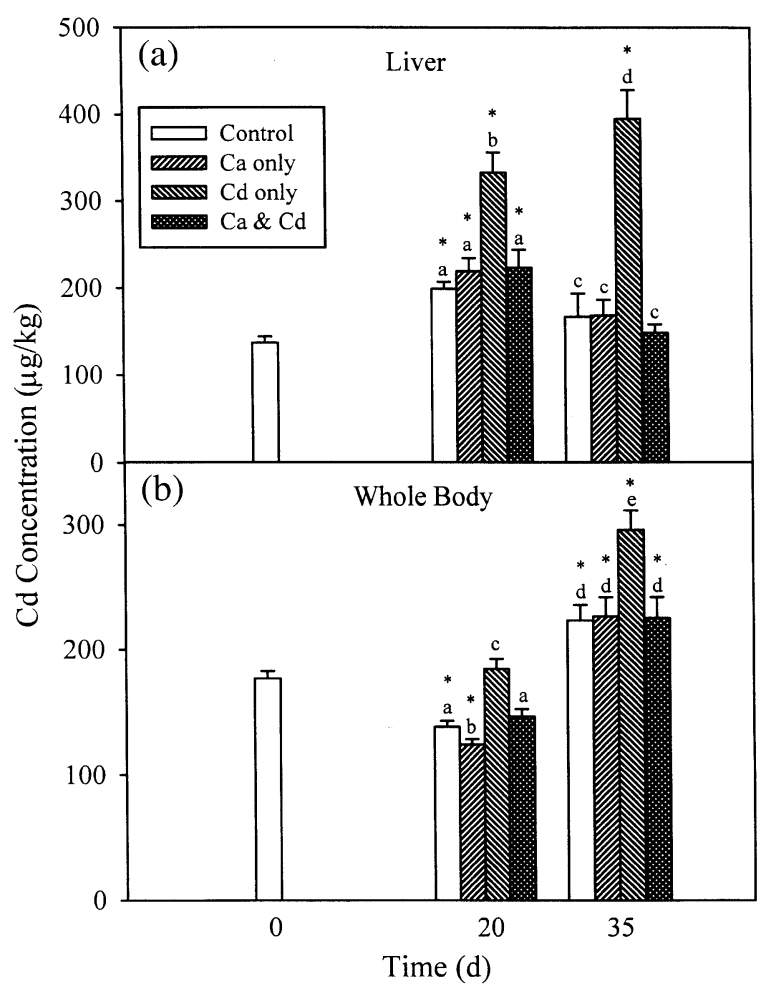

Fig. 3. Accumulation of Cd in liver (a) and whole body (b) of juvenile rainbow trout during 35 days. Day 10 liver tissues were lost. Same format as Fig. 2. 


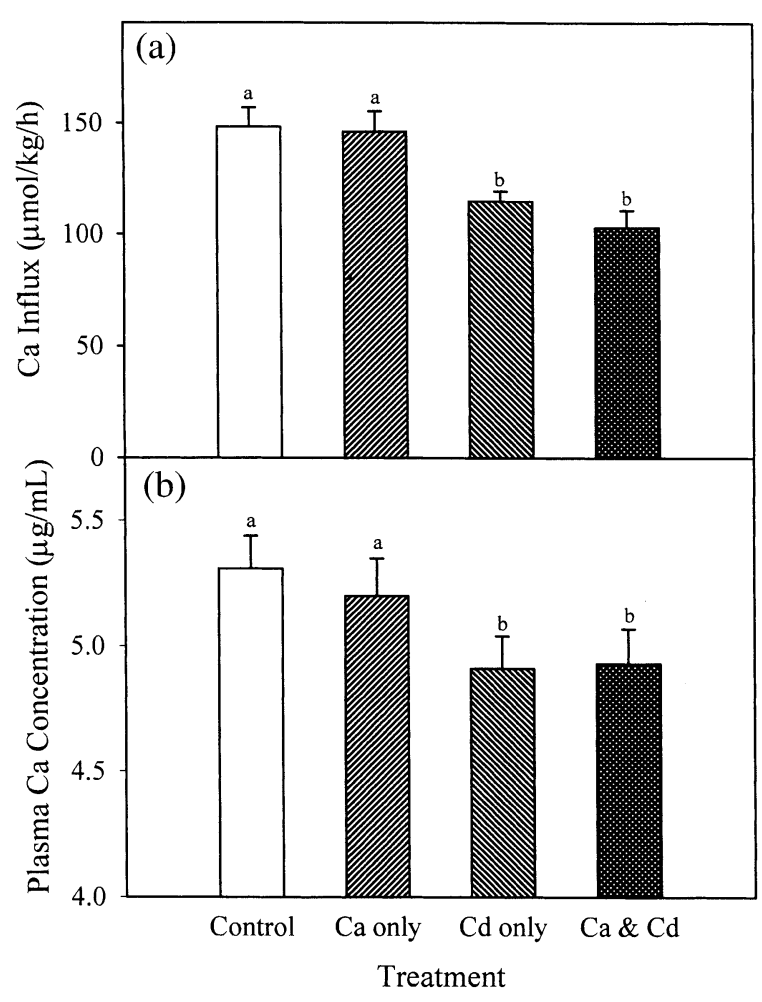

Fig. 4. (a) Unidirectional $\mathrm{Ca}^{2+}$ flux into gills over $4 \mathrm{~h}$ and (b) plasma $\mathrm{Ca}$ concentration in juvenile rainbow trout on day 40 . Fish ( $\mathrm{Ca}^{2+}$ flux: $n=12$; plasma Ca: $\left.n=35-40\right)$ were sampled from each treatment (two replicates): 'control' (no supplemented $\mathrm{Ca}$ diet or waterborne $\mathrm{Cd}$ ), 'Ca only' (supplemented $\mathrm{Ca}$ diet and no waterborne $\mathrm{Cd}$ ), ' $\mathrm{Cd}$ only' (waterborne $\mathrm{Cd}$ and no supplemented $\mathrm{Ca}$ diet), and ' $\mathrm{Ca}$ and $\mathrm{Cd}$ ' (both supplemented $\mathrm{Ca}$ diet and waterborne $\mathrm{Cd}$ ). Treatments sharing the same letter are not significantly different; $P<0.05$.

reported (Benoit et al., 1976; Giles, 1988). At the gills, cadmium has been shown to enter through chloride cells and accumulate therein (Wicklund Glynn et al., 1994) and pass into the blood stream across the basolateral membrane by an unknown mechanism (Verbost et al., 1987, 1989). It is not known how it is targeted to the various organs, though the rates of tissue-specific accumulation must relate to the rate of branchial entry. In the present study, an approximate doubling of dietary calcium significantly inhibited cadmium accumulation in gill by $75 \%$, in kidney by $72 \%$, in liver by $62 \%$, and in whole body by $24 \%$ relative to controls (Figs. 2 and 3). Despite the dramatic inhibition of cadmium accumulation in gill and kidney tissues induced by dietary calcium, cadmium levels remained elevated compared to the control gill and kidney cadmium concentrations (Fig. 2). During the 35-day exposure, even background cadmium levels dropped in gills of dietary calcium treated fish (40\% drop; Fig. 2a). Studies on waterborne calcium have shown similar findings. Hollis et al. $(1999,2000)$ reported that waterborne calcium reduced cadmium accumulation in gill, liver and kidney tissues by inhibiting cadmium uptake at gills. In theory, elevated dietary calcium may gradually induce elevation of plasma calcium. Consequently, plasma calcium may leak into the ionocytes from the blood across the basolateral membrane and induce apical calcium channel closure directly or indirectly, thereby, preventing further cadmium influx from the water into the gill and internal tissues. While plasma calcium was not elevated in the present measurements, it must be remembered that these measurements (Fig. $4 b$ ) were taken only at the end of the exposure after suspension of the dietary regime, when the gill pattern was already well established (Fig. 2a).

Waterborne cadmium competes for high affinity calcium binding sites on the gill surface (Playle et al., 1993a,b; Playle, 1998) and inhibits the basolateral high affinity $\mathrm{Ca}^{2+}$-ATPase (Verbost et al., 1987, 1988, 1989), thereby causing a $26 \%$ drop in unidirectional calcium flux from water into the gills relative to controls (Fig. 4a). Reid and McDonald (1988) and Hollis et al. (1999) similarly reported reduced unidirectional calcium influx into whole body of rainbow trout that were exposed to waterborne cadmium. Cadmium has also been reported to cause changes to the ultrastructure of the gill epithelium (Pratap and Wendelaar Bonga, 1993). Dietary calcium by itself, on the other hand, did not alter unidirectional calcium flux from water into the gills (Fig. 4a).

In the presence of cadmium, dietary calcium caused a significant elevation of calcium concentration $(P<0.05)$ in gills of rainbow trout on day 20 (Fig. 5a). However, when fish were fed a normal diet, waterborne cadmium caused a significant decrease in calcium concentration in the gills on day 35 (Fig. 5a) and in plasma on day 40 (Fig. 4a). The latter observation was a 'snap shot' of plasma calcium concentration at the end of the experiment. Although hypocalcemia has been observed in plasma of fish exposed to $10 \mu \mathrm{g} / \mathrm{l}$ waterborne cadmium, calcium concentrations eventually recovered (Pratap et al., 1989). Calcium homeostasis in gill ionocytes is probably regulated via several plasma membrane calcium transport mechanisms (reviewed in Schoenmakers et al., 1992). At the basolateral plasma mem- 

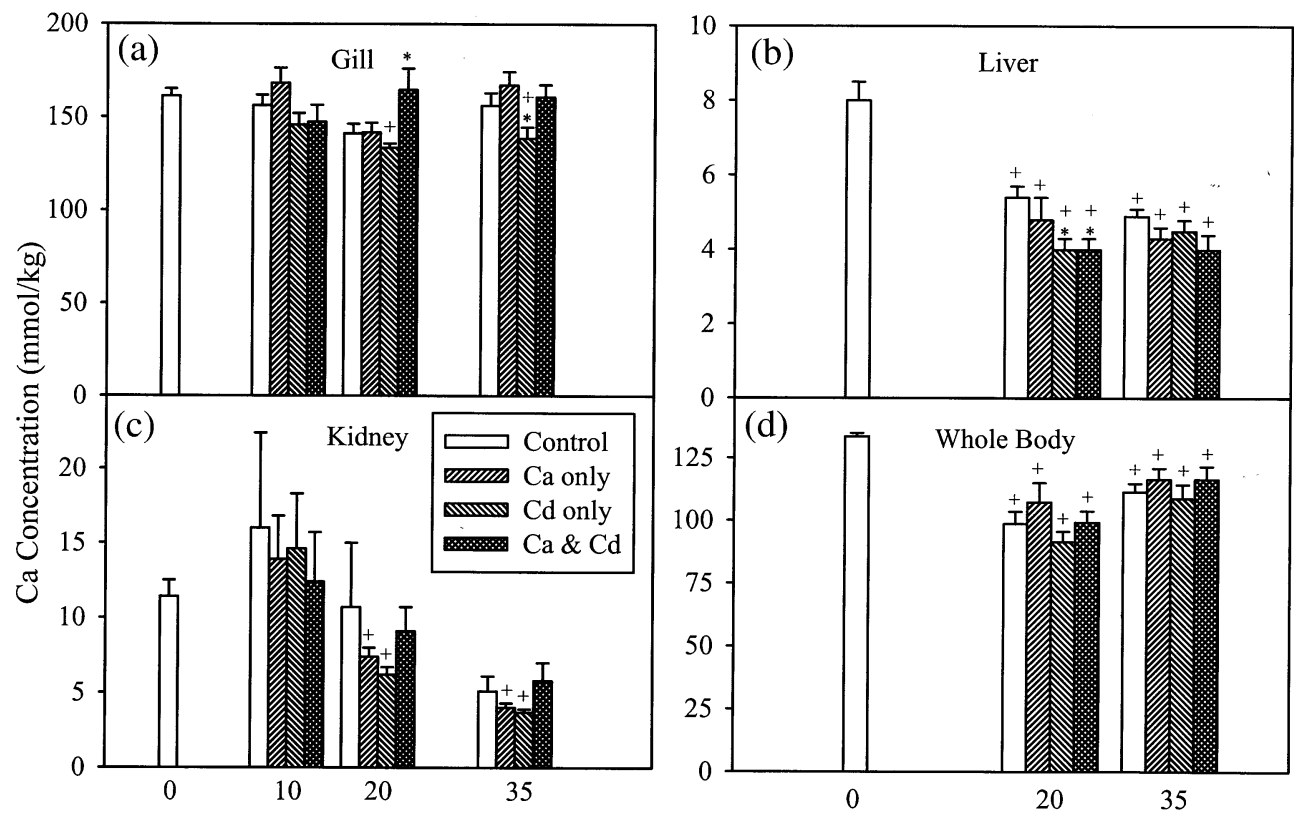

Time (d)

Fig. 5. Concentration of $\mathrm{Ca}$ in gill (a), liver (b), kidney (c), and whole body (d) of juvenile rainbow trout during 35 days. Fish (0 days: $n=16 ; 10,20$, and 30 days: $n=12$ ) were sampled from each treatment (two replicates): 'control' (no supplemented Ca diet or waterborne $\mathrm{Cd}$ ), 'Ca only' (supplemented $\mathrm{Ca}$ diet and no waterborne $\mathrm{Cd}$ ), 'Cd only' (waterborne $\mathrm{Cd}$ and no supplemented $\mathrm{Ca}$ diet), and ' $\mathrm{Ca}$ and Cd' (both supplemented $\mathrm{Ca}$ diet and waterborne $\mathrm{Cd}$ ). Statistical comparisons were made among treatments at each sampling day against the control $(*)$ and temporally against the initial control $(+) ; P<0.05$.

brane, calcium is transported mainly by the $\mathrm{Ca}^{2+}$-ATPase and to a small extent by the $\mathrm{Ca}^{2+} / \mathrm{Na}^{+}$exchanger, and at the apical plasma membrane, calcium normally enters via second messenger operated calcium channels (SMOCs) (Verbost et al., 1987, 1988, 1989; reviewed in Flik et al., 1993). In the presence of cadmium, first $\mathrm{Ca}^{2+}$-ATPase activity and later SMOCs are inhibited (Verbost et al., 1987, 1989). Consequently, blockade of calcium transport may lead to inhibition of calcium extrusion from ionocytes, and thereby contribute to the observed elevation of calcium concentration in the gill tissue. However, in the absence of dietary calcium, cadmium may effectively block the main calcium uptake route (waterborne) causing hypocalcemia in gills and plasma (Fig. 4).

Based on our findings on the distribution patterns of cadmium and calcium, as well as recent findings on calcium and cadmium transport in the gills of rainbow trout, we postulate an hypothesis to explain our result in the context of calcium homeostasis. Possibly, the combined effects of calcium leakage into the gill cells from the blood, inhibition of calcium extrusion from cytoplasm by cadmium, and inhibition of calcium efflux into the water may lead to calcium buildup in the gill cells of fish exposed to waterborne $\mathrm{Cd}$ in the presence of high dietary calcium. The rise in plasma calcium may induce mobilization of stanniocalcin, a calcitropic hormone known to regulate the activity of SMOCs via a second messenger (reviewed in Flik et al., 1993). In turn, stanniocalcin release may inhibit calcium and cadmium influx through the SMOCs, thereby disrupting calcium homeostasis and leading eventually to hypocalcemia in plasma and reduced cadmium accumulation in body tissues. Alternately, via a stanniocalcin-independent pathway, dietary calcium may interact with calmodulin leading to inhibition of SMOCs, thereby, again inhibiting calcium and cadmium influx.

Despite its protective effects on cadmium accumulation, dietary calcium supplementation seemed to be associated with mortality, at least in the presence of waterborne cadmium, but the phenomenon did not start until after day 20 (Fig. 1). On the other hand, cadmium exposed fish that 
were fed control diet did not show significant mortality. Studies on non-aquatic organisms, such as humans (Gamble et al., 1925), bovines (Oetzel et al., 1991; Goff and Horst, 1993) and rats (Classen et al., 1995), have shown that some inorganic calcium salts, specifically calcium chloride, when fed in the diet may induce severe metabolic acidosis, which in turn disrupts ionoregulatory balance. In a separate study, we observed abnormal behavior (such as vomiting, neurological dysfunction, hemorrhage, and constipation) and substantial rapid mortality in fish fed high concentrations of calcium chloride or calcium nitrate even when not exposed to waterborne cadmium. The phenomenon of mortality is currently under investigation.

In conclusion, this study has shown that waterborne cadmium and dietary calcium interact via two separate mechanisms. First, dietary calcium inhibits waterborne cadmium accumulation in gill, liver, kidney, and whole body of rainbow trout. Second, waterborne cadmium inhibits unidirectional calcium flux from the water into the gills. However, dietary calcium does not protect against hypocalcemia induced by waterborne cadmium. In addition, a combination of elevated dietary calcium and waterborne cadmium actually leads to increased toxicity in rainbow trout. Thus if trout under chronic waterborne Cd exposure in a field situation were to switch their diet to more calcium-rich food sources (e.g. from fish and insects to benthic mollusks and crustaceans), they might gain some benefits in reducing long term cadmium accumulation, though implications for survival are unclear.

\section{Acknowledgements}

This research was supported by a grant from The Metals In The Environment Research Network (MITE-RN) funded by NSERC, the Mining Association of Canada, and Ontario Power Generation. The authors thank Collins Kamunde and Jacqui Dockray for their assistance with this project, Dr D.G. McDonald for advice, and Drs Peter Chapman, Robert Garrett, and Gregory Pope for helpful comments on the manuscript and two reviewers for constructive criticism. CMW is supported by the Canada Research Chair Program.

\section{References}

Ball, I.R., 1967. The toxicity of cadmium to rainbow trout (Salmo gairdneri Richardson). Water Res. 1, 805-806.

Benoit, D.A., Leonard, E.N., Christensen, G.M., Fiandt, J.T., 1976. Toxic effects of cadmium on three generations of brook trout (Salvelinus fontinalis). Trans. Am. Fish. Soc. 105, 550-560.

Calamari, D., Marchetti, R., Vailati, G., 1980. Influence of water hardness on cadmium toxicity to Salmo gairdneri Rich. Water Res. 14, 1421-1426.

Carrol, J.J., Ellis, S.J., Oliver, W.S., 1979. Influences of hardness constituents on the acute toxicity of cadmium to brook trout (Salvelinus fontinalis). Bull. Environ. Contam. Toxicol. 22, 575-581.

Classen, H.G., Schutte, K., Schimatschek, H.F., 1995. Different effects of three high-dose oral calcium salts on acid-base metabolism, plasma electrolytes and urine parameters of rats. Methods Find. Exp. Clin. Pharmacol. 17, 437-442.

Davies, P.H., Gorman, W.C., Carlson, C.A., Brinkman, S.F., 1993. Effect of hardness on bioavailability and toxicity of cadmium to rainbow trout. Chem. Speciation Bioavailability 5, 67-77.

Flik, G., Van der Velden, J.A., Dechering, K.J. et al., 1993. $\mathrm{Ca}^{2+}$ and $\mathrm{Mg}^{2+}$ transport in gills and gut of tilapia, Oreochromis mossambicus: a review. J. Exp. Zool. 265, 356-365.

Gamble, J.L., Blackfan, K.D., Hamilton, B., 1925. A study of the diuretic action of acid producing salts. J. Clin. Invest. 1, 359-388.

Gardner, G.R., Yevich, P.P., 1970. Histological and hematological responses of an estuarine teleost to cadmium. J. Fish. Res. Bd. Can. 27, 2185-2196.

Giles, M.A., 1988. Accumulation of cadmium by rainbow trout, Salmo gairdneri, during extended exposure. Can. J. Fish. Aquat. Sci. 45, 1045-1053.

Goff, J.P., Horst, R.L., 1993. Oral administration of calcium salts for treatment of hypocalcemia in cattle. J. Dairy Sci. 76, 101-108.

Hogstrand, C., Wilson, R.W., Polgar, D., Wood, C.M., 1994. Effects of zinc on the kinetics of branchial calcium uptake in freshwater rainbow trout during adaptation to waterborne zinc. J. Exp. Biol. 186, 55-73.

Hollis, L., Muench, L., Playle, C., 1997. Influence of dissolved organic matter on copper binding, and calcium and cadmium binding, by gills of rainbow trout. J. Fish. Biol. 50, 703-720.

Hollis, L., McGeer, J.C., McDonald, D.G., Wood., C.M., 1999. Cadmium accumulation, gill $\mathrm{Cd}$ binding, acclimation, and physiological effects during long-term sublethal $\mathrm{Cd}$ exposure in rainbow trout. Aquat. Toxicol. 46, 101-119. 
Hollis, L., McGeer, J.C., McDonald, D.G., Wood., C.M., 2000. Protective effects of calcium against chronic waterborne cadmium exposure to juvenile rainbow trout. Environ Toxicol. Chem. 19, 2725-2734.

Hunn, J.B., 1985. Role of calcium in gill function in freshwater fishes. Comp. Biochem. Physiol. 82A, 543-547.

Mason, C.F., 1996. Biology of Freshwater Pollution, 3rd ed Longman, Harlow.

Oetzel, G.R., Fettman, M.J., Hamar, D.W., Olson, J.D., 1991. Screening of anionic salts for palatability, effects on acid-base status, and urinary calcium excretion in dairy cows. J. Dairy Sci. 74, 965-971.

Pagenkopf, G.K., 1983. Gill surface interaction model for trace-metal toxicity to fishes: role of complexation, $\mathrm{pH}$, and water hardness. Environ. Sci. Technol. 17, 342-347.

Pärt, P., Svanberg, O., Kiessling, A., 1985. The availability of cadmium to perfused rainbow trout gills in different water qualities. Water Res. 19, 427-434.

Pascoe, D., Evans, S.A., Woodworth, J., 1986. Heavy metal toxicity to fish and the influence of water hardness. Arch. Environ. Contam. Toxicol. 15, 481-487.

Perry, S.F., Wood, C.M., 1985. Kinetics of branchial calcium uptake in the rainbow trout: effects of acclimation to various external calcium levels. J. Exp. Biol. 116, 411-433.

Playle, R.C., 1998. Modeling metal interactions at fish gills. Sci. Total Environ. 219, 147-163.

Playle, R.C., Dixon, D.G., Burnison, K., 1993a. Copper and cadmium binding to fish gills: modification by dissolved organic carbon and synthetic ligands. Can. J. Fish. Aquat. Sci. 50, 2667-2677.

Playle, R.C., Dixon, D.G., Burnison, K., 1993b. Copper and cadmium binding to fish gills: estimates of metal-gill stability constants and modeling of metal accumulation. Can. J. Fish. Aquat. Sci. 50, 2678-2687.

Pratap, H.B., Wendelaar Bonga, S.E., 1993. Effects of ambient and dietary cadmium on pavement cells, chloride cells, and $\mathrm{Na}^{+} / \mathrm{K}^{+}$-ATPase activity in the gills of the freshwater teleost Oreochromis mossambicus at normal and high calcium levels in the ambient water. Aquat. Toxicol. 26, 133-150.

Pratap, H.B., Fu, H., Lock, R.A.C., Wendelaar Bonga, S.E., 1989. Effect of waterborne and dietary cadmium on plasma ions of teleost Oreochromis mossambicus in relation to water calcium levels. Arch. Environ. Toxicol. 18, 568-575.

Reid, S.D., McDonald, D.G., 1988. Effects of cadmium, copper, and low $\mathrm{pH}$ on ion fluxes in the rainbow trout, Salmo gairdneri. Can. J. Fish. Aquat. Sci. 45, 244-253.

Richards, J.G., Playle, R.C., 1999. Protective effects of calcium against the physiological effects of exposure to a combination of cadmium and copper in rainbow trout (Oncorhynchus mykiss). Can. J. Zool. 77, 1035-1047.

Roberts, K.S., Cryer, A., Kay, J. et al., 1979. The effects of exposure to sub-lethal concentration of cadmium on enzyme activities and accumulation of the metal in tissues and organs of rainbow and brown trout (Salmo gairdneri, Richardson and Salmo trutta Fario L.). Comp. Biochem. Physiol. 62C, 135-140.

Roch, M., Maly, E.J., 1979. Relationship of cadmiuminduced hypocalcemia with mortality in rainbow trout (Salmo gairdneri) and the influence of temperature on toxicity. J. Fish. Res. Bd. Can. 36, 1297-1303.

Schoenmakers, T.J.M., Klaren, P.H.M., Flik, G., Lock, R.A.C., Pang, P.K.T., Wendelaar Bonga, S.E., 1992. Actions of cadmium on basolateral plasma membrane proteins involved in calcium uptake by fish intestine. J. Membrane Biol. 127, 161-172.

Verbost, P.M., Flik, G., Lock, R.A.C., Wendelaar Bonga, S.E., 1987. Cadmium inhibition of $\mathrm{Ca}^{2+}$ uptake in rainbow trout gills. Am. J. Physiol. 253, R216-R221.

Verbost, P.M., Flik, G., Lock, R.A.C., Wendelaar Bonga, S.E., 1988. Cadmium inhibits plasma membrane calcium transport. J. Membrane Biol. 102, 97-104.

Verbost, P.M., Van Rooij, J., Flik, G., Lock, R.A.C., Wendelaar Bonga, S.E., 1989. The movement of cadmium through freshwater trout branchial epithelium and its interference with calcium transport. J. Exp. Biol. 145, 185-197.

Wetzel, R.G., 1983. Limnology, 2nd ed Saunders College Publ, Philadelphia, PA, pp. 207-208.

Wicklund Glynn, A., Norrgren, L., Müssener, A., 1994. Differences in uptake of inorganic mercury and cadmium in the gills of the zebrafish, Brachydanio rerio. Aquat. Toxicol. 30, 13-26. 